\title{
The impact of the maternal's periodontal status on the detection of periodontal pathogens in newborn children
}

\author{
O impacto da condição periodontal materna na detecção de \\ patógenos periodontais em recém-nascidos
}

\begin{abstract}
Purpose: To evaluate the influence of the mother's periodontal clinical status on the prevalence of periodontal pathogens in newborns.

Methods: Seventy-six pairs of newborns and their biological mothers were selected. After a periodontal examination, the mother-child pairs were divided into two groups according to their maternal periodontal clinical status: mothers with (Group $A, n=33$ ) or without periodontitis (Group B, $n=43$ ). The oral colonization of newborns by five periodontopathogens ( $A$. actinomycetemcomitans, P. intermedia, P. gingivalis, T. forsythia and C. rectus) was determined using a DNA-specific PCR method. Statistical analysis was performed using the Chi-square test at the significant level of 0.05 .

Results: C. rectus was the most prevalent species observed (23.25\%) in Group B, while in Group A P. gingivalis (96.97\%) had the highest detection rate, followed by T. forsythia $(60.60 \%)$ and P. intermedia (39.39\%). Between-groups comparisons showed a greater frequency of all study pathogens among newborns from Group A.

Conclusion: The maternal clinical periodontal status was a satisfactory indicator of the bacterial colonization pattern observed in their newborn children. Thus, longitudinal studies should be performed to confirm this relationship.
\end{abstract}

Key words: Infant; periodontitis; bacteria; polymerase chain reaction

\section{Resumo}

Objetivo: Avaliar a influência do estado clínico periodontal materno sobre a prevalência de patógenos periodontais em recém-nascidos.

Metodologia: Setenta e seis pares de recém-nascidos e suas mães biológicas foram selecionados. Após o exame periodontal, os pares mãe-criança foram divididos em dois grupos Segundo o estado clínico periodontal materno: mães com (Grupo $A, n=33$ ) ou sem periodontite (Grupo B, $n=43$ ). A colonização oral de recém-nascidos por cinco patógenos peridontais (A. actinomycetemcomitans, P. intermedia, P. gingivalis, T. forsythia e C. rectus) foi determinada usando um método PCR DNA-específico. A análise estatística foi realizada usando teste qui-quadrado ao nível de significância de 0,05.

Resultados: C. rectus foi a espécie mais prevalente $(23,25 \%)$ no Grupo B, enquanto no Grupo A P. gingivalis $(96,97 \%)$ teve a maior taxa de detecção, seguido de T. forsythia $(60,60 \%)$ e P. intermedia (39,39\%). As comparações entre-grupos mostraram uma maior frequência de todos os patógenos estudados entre os recém-nascidos do Grupo A.

Conclusão: $O$ estado clínico periodontal materno foi um indicador satisfatório do padrão de colonização bacteriana observado em recém-nascidos. Assim, estudos longitudinais devem ser realizados para confirmar esta relação.

Palavras-chave: Infante; periodontite; bactéria; reação em cadeia da polimerase

\author{
Davi Romeiro Aquino a \\ Gilson Cesar Nobre Franco a \\ José Roberto Cortelli a \\ Fernando Oliveira Costa b \\ Alexandre Prado Scherma a \\ Sheila Cavalca Cortelli a
}

\begin{abstract}
a Department of Dentistry, University of Taubate, Taubaté, SP, Brazil

b Department of Periodontology, Federal University of Minas Gerais, Belo Horizonte, MG, Brazil
\end{abstract}

\author{
Correspondence: \\ Davi Romeiro Aquino \\ Rua Expedicionário Ernesto Pereira, 110 - Centro \\ Taubaté, SP - Brazil \\ 12020-330 \\ E-mail:daviaquino@uol.com.br
}

Received: April 30, 2010

Accepted: September 27, 2010

Conflict of Interest Statement: The authors state that there are no financial and personal conflicts of interest that could have inappropriately influenced their work.

Copyright: (C) 2010 Aquino et al.; licensee EDIPUCRS. This is an Open Access article distributed under the terms of the Creative Commons AttributionNoncommercial-No Derivative Works 3.0 Unported License. 


\section{Introduction}

Among the several pathogens that are known to be related to periodontal disease, Aggregatibacter actinomycetemcomitans, Porphyromonas gingivalis, Prevotella intermedia, Tannerella forsythia and Campylobacter rectus can be found in individuals with different severities of periodontitis (1-3). However, studies that evaluate the pattern of transmission have primarily focused on the prevalence of $A$. actinomycetemcomitans and P. gingivalis (4), while the acquisition of other key periodontal pathogens remains to be elucidated (5). More recently, the potential for bacterial transmission has been focus of a number of studies (5-7) that attempted to investigate the precise moment when the first contact between the individual and the periodontal pathogen occurs (8). Unfortunately, the precise moment when underlying the acquisition of the periodontal pathogen take place remains unclear (9). Moreover, these studies have failed to conclusively determine whether or not this first colonization event is transitory or whether this event may function to increase the future risk for the establishment of the periodontal disease $(7,10)$.

Umeda et al. (11) evaluated the distribution of periodontal pathogens in 56 children (from 1 to 15 years old) and their parents. A PCR-based method was used to determine the prevalence of microbial organisms in saliva and dental plaque samples. A positive correlation was observed for the presence of oral pathogens between parents and their children. Thus, the authors suggested a possible vertical familiar transmission of those periodontal pathogens. In a separate study, Kobayashi et al. (12) also investigated the progress of infection by periodontal pathogens and the role of the child's mother in this transmission process. The results indicated that the colonization of periodontal bacterial in children increased with age and that the bacterial microbiota in children was very similar to that in their mothers. Nevertheless, in both studies, information regarding the exact moment of this first colonization event was not elucidated due to the lack of conclusive data.

It is important to emphasize that transmission studies of children-parent pairs have primarily aimed to determine if the pathogen found in a given child is exactly the same microbial strain recovered from the mother or the father. As a diagnostic method, this kind of analysis is very limited, especially in developing countries, because this method is time-consuming and cost-ineffective. Comparisons between periodontally diseased or healthy patients have demonstrated that the first group possesses higher levels of bacteria (13). Thus, as suggested by Tamura et al. (5), it seems reasonable that oral cavities from mothers with periodontal disease can act as potential reservoirs of pathogens that may procure an early oral bacterial colonization event in their children. However, the direct impact of the maternal periodontal status established by a cheaper and faster clinical examination technique has not been studied. Therefore, it was hypothesized that even after a fairly short period of time following birth, newborns whose mothers had periodontal disease may present a higher prevalence of pathogens than newborns whose mothers are periodontally healthy.

\section{Methodology}

\section{Population}

The protocol was approved by the ethical research committee (University of Taubaté Ethics Committee, protocol \#0317/07). The mothers of the children received detailed information regarding the nature and the procedures involved in the study and signed informed consent forms. In order to establish the sample size of the present study, a pilot project was performed with four newborns (Chi-square- $\mathrm{X}^{2}, \alpha$ significance level from 1 to $5 \%$ and a test power equivalent to $80 \%$ ).

Seventy-six newborns (maximum age of three months) and their mothers were included in this cross-sectional study. A complete periodontal examination was performed at the dental clinic by the same trained and calibrated examiner immediately before microbial samples were collected to measure the probing pocket depth, the clinical attachment level, the plaque and bleeding upon probing scores. Based on the obtained clinical record, all of the mothers were classified as periodontitis patients according to López's criteria, which indicate that they have at least four periodontal sites with a $\mathrm{PD} \geq 4 \mathrm{~mm}$ and $\mathrm{CAL} \geq 3 \mathrm{~mm}$ distributed in different teeth (14). Therefore, according to the maternal clinical periodontal status, the pairs were divided into two groups, specifically newborns whose mothers were diagnosed with periodontal disease (Group A, n=33) and newborns whose mothers were diagnosed as not possessing periodontal disease (Group B, $\mathrm{n}=43$ ). All of the clinical and microbial examinations were performed between July 2007 and December 2007. The medical and dental information from additional pairs was obtained using a questionnaire, and only newborns who had close contact with their mothers were included. Therefore, newborns who spent a significant amount of time with nurses, nannies or relatives were excluded from the study. In addition, in order to minimize the time of contact with siblings and other members of their respective families, only newborns with a birth date occurring after the beginning of the academic school year were accepted for this study.

\section{Microbial procedures}

Microbial samples were taken from the dorsum of the tongue of all newborns according to method described by Cortelli et al. (2). Briefly, the samples were taken from areas of approximately $1 \mathrm{~cm}^{2}$ using a swab with reduced Ringer's solution that was rotated six times. Each swab was transferred into a microtube also containing reduced Ringer's solution $(1 \mathrm{~mL})$ and frozen $\left(-80^{\circ} \mathrm{C}\right)$ until the time of the analysis.

The bacterial cells in the microtube were dispersed using a Vortex and centrifuged for 3 minutes at 12,000 rpm. From the cellular bacteria pellet, genomic DNA was extracted using a commercial DNA purification Kit (InstaGene ${ }^{\circledR}$, Bio-Rad laboratories, Hercules, CA, USA) according to the manufacturer's instructions. To confirm the presence of bacterial DNA, an amplification assay was performed by using universal 16S rRNA primers (Table 1). 
Table 1. Bacteria-specific primers and PCR-product sizes (base pairs).

\begin{tabular}{|c|c|c|}
\hline Bacteria & Primers & Base Pairs \\
\hline Universal 16rRNA & $\begin{array}{l}\text { 5'-GATTAGATACCCTGGTAGTCCAC-3' } \\
\text { 5'-CCCGGGAACGTATTCACCG-3' } \\
\text { Ashimoto et al. (15) }\end{array}$ & 602 \\
\hline A. actinomycetemcomitans & $\begin{array}{l}\text { 5'-AAACCCATCTCTGAGTTCTTCTTC-3' } \\
\text { 5'-ATGCCAACTTGACGTTAAAT-3' } \\
\text { Ashimoto et al. (15) }\end{array}$ & 550 \\
\hline$P$. gingivalis & $\begin{array}{l}\text { 5'-AGGCAGCTTGCCATACTGCG-3' } \\
\text { 5'-ACTGTTAGCAACTACCGATGT-3' } \\
\text { Slots et al. (16) }\end{array}$ & 404 \\
\hline P. intermedia & $\begin{array}{l}\text { 5'-TTTGTTGGGGAGTAAAGCGGG-3' } \\
\text { 5'-TCAACATCTCTGTATCTGCGT-3' } \\
\text { Ashimoto et al. (15) }\end{array}$ & 575 \\
\hline T. forsythia & $\begin{array}{l}\text { 5'-GCGTATGTAACCTGCCCGCA-3' } \\
\text { 5'-TGCTTCAGTGTCAGTTATACCT-3' } \\
\text { Slots et al. (16) }\end{array}$ & 641 \\
\hline C. rectus & $\begin{array}{l}\text { 5'-TTTCGGAGCGTAAACTCCTTTT-3' } \\
\text { 5'-TTTCTGCAAGCAGACACTCTT-3' } \\
\text { Slots et al. (16) }\end{array}$ & 598 \\
\hline
\end{tabular}

The prevalence of C. rectus, P. gingivalis, A actinomycetemcomitans, $P$. intermedia and $T$. forsythia was determined by polymerase chain reaction (PCR). A total volume of $25 \mu \mathrm{L}$ of the PCR mixture contained $10 \mu \mathrm{L}$ of the DNA sample, 2.5 $\mu \mathrm{L}$ of a 10x PCR buffer (Invitrogen, Carlsbad, CA, USA), 1.25 units of Taq DNA polymerase (Invitrogen), $0.2 \mathrm{mM}$ of each deoxyribonucleotide (Invitrogen, Carlsbad, CA, USA), $1.5 \mathrm{mM}$ of $\mathrm{MgCl}_{2}$ and $1.0 \mu \mathrm{M}$ of each primer.

The PCR amplification was performed in a Mastercycler Gradient thermal cycler (Eppendorf, Westbury, NY, USA) using a standard protocol that includes an initial denaturation step at $95{ }^{\circ} \mathrm{C}$ for 5 minutes, followed by 35 cycles of denaturation at $95{ }^{\circ} \mathrm{C}$ for 30 seconds, an annealing step at $55^{\circ} \mathrm{C}$ for 30 seconds, and an extension step at $72{ }^{\circ} \mathrm{C}$ for 1 minute, with a final extension period of $72^{\circ} \mathrm{C}$ for 5 minutes. The bacterium-specific primer ( $\left.5^{\prime}-3^{\prime}\right)$ sequences used in this study are shown in Table 1.

The final products were separated on $1.5 \%$ agarose gel, stained with ethidium bromide $(0.5 \mu \mathrm{g} / \mathrm{mL})$ and photographed under ultraviolet light to confirm the existence of the target oral bacterial species. A 100 bp DNA ladder (Invitrogen, Carlsbad, CA, USA) was used as the molecular weight marker. Both positive and negative controls were included for the PCR reaction in order to verify the primer specificity and identify and DNA contamination.

\section{Statistical analysis}

The frequencies of the periodontal pathogens were analyzed using the Chi-squared test $\left(\mathrm{X}^{2}\right)$. Statistical analyses were performed using statistical software (Bio Estat 5.0 and SPSS11.0) where the statistical significance was established at $5 \%$.

\section{Results}

In the present study the 76 newborns who were analyzed were composed of 34 males and 42 females, where 43 of the children had mothers without periodontal disease and the remaining 33 children had mothers with periodontal disease (Table 2).

Table 2. Distribution of the population.

\begin{tabular}{lccc}
\hline & \multicolumn{2}{c}{ Maternal periodontal clinical status } & \\
\cline { 2 - 3 } & $\begin{array}{c}\text { Group A } \\
\text { Periodontitis }+\end{array}$ & $\begin{array}{c}\text { Group B } \\
\text { Periodontitis - }\end{array}$ & Total \\
\hline Male & 9 & 25 & 34 \\
Female & 24 & 18 & 42 \\
Total & 33 & 43 & 76 \\
$(\mathrm{Ml} \pm$ SD) & $(1.57 \pm 0.86)$ & $(2.83 \pm 1.60)$ & $(2.28 \pm 1.46)$ \\
\hline
\end{tabular}

$\mathrm{MI}$ - Mean age in months; SD - Standard deviation.

In newborns of the mothers without periodontal disease, $C$. rectus was observed more often $(P<0.05)$ than other bacterial species (Fig. 1). On the other hand, in the group of children whose mothers were affected by periodontal disease, $P$. gingivalis was the most prevalent pathogen observed $(P<0.05)$, followed by $P$. intermedia, $T$. forshythia, $C$. rectus, and A. actinomycetemcomitans (Fig. 2).

With the exception of $C$. rectus, the between-groups comparison regarding the prevalence of the studied pathogens revealed a higher prevalence of bacteria $(P<0.05)$ among newborns from Group A when compared to the newborns from Group B (Table 3). 


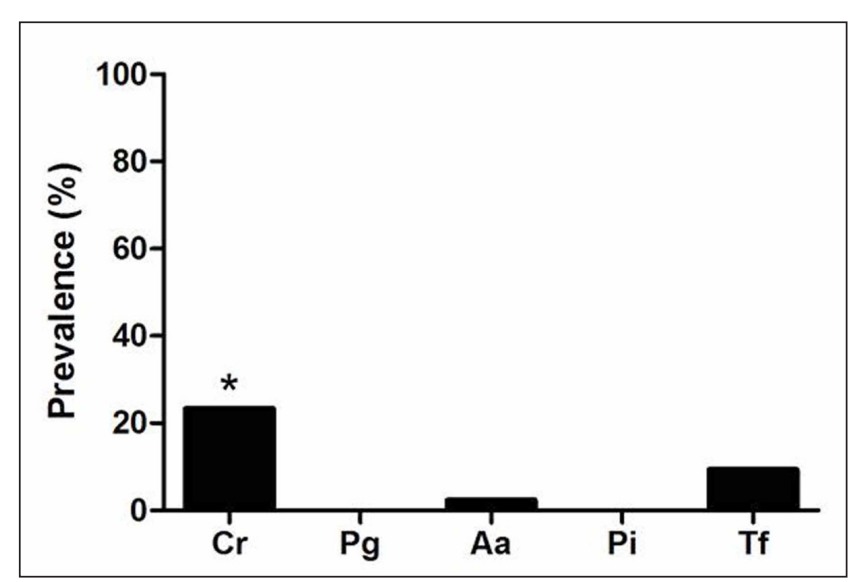

Fig. 1. The oral distribution of periodontal pathogens within the newborns from mothers without periodontal disease. ${ }^{*}$ Interspecies comparisons: statistically significant difference $-P<0.05$, Chi-square test).

Table 3. The oral frequencies $(F)$ of periodontal pathogens in newborns according to the maternal clinical periodontal status.

\begin{tabular}{|c|c|c|c|c|c|c|c|}
\hline & & & $\mathrm{Cr}$ & $\mathrm{Pg}$ & $\mathrm{Aa}$ & $\mathrm{Pi}$ & Tf \\
\hline$\frac{2}{\frac{1}{0}} \frac{5}{\frac{1}{n}}$ & $\stackrel{n}{ \pm}$ & + & 10 & 0 & 1 & 0 & 4 \\
\hline 㐫 & 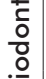 & - & 33 & 43 & 42 & 43 & 39 \\
\hline$\frac{u}{\frac{0}{t}}$ & 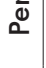 & $\mathrm{F}$ & $23.25 \%$ & $0.00 \%$ & $2.32 \%$ & $0.00 \%$ & $9.30 \%$ \\
\hline . & $\begin{array}{l}+ \\
\stackrel{\varrho}{ \pm}\end{array}$ & + & 6 & 32 & 6 & 13 & 20 \\
\hline $\bar{\sigma}$ & $\begin{array}{l}\vec{t} \\
\text { o } \\
0\end{array}$ & - & 27 & 1 & 27 & 20 & 13 \\
\hline$\sum^{\frac{\pi}{0}}$ & $\stackrel{\bar{\omega}}{0}$ & $\mathrm{~F}$ & $18.18 \%$ & $96.97 \%$ & $18.18 \%$ & $39.39 \%$ & $60.60 \%$ \\
\hline \multicolumn{3}{|c|}{$P$-value } & 0.5907 & 0.0000 & 0.0489 & 0.0000 & 0.0018 \\
\hline
\end{tabular}

Finally, the estimated odds ratio for the relative risk of the acquisition of periodontal pathogens in the different groups was determined. The results indicated no significant difference between the maternal periodontal status and the acquisition of periodontal pathogens.

\section{Discussion}

Arriving at an early diagnosis for any pathology must always be the aim of every health care professional. However, for periodontal disease, the diagnosis has been achieved in most cases only after the manifestation of the disease's clinical symptoms.

Periodontal disease is one of the most common chronic infections in adults, affecting approximately 4 to $19 \%$ of the population of Central and South America (17). Once

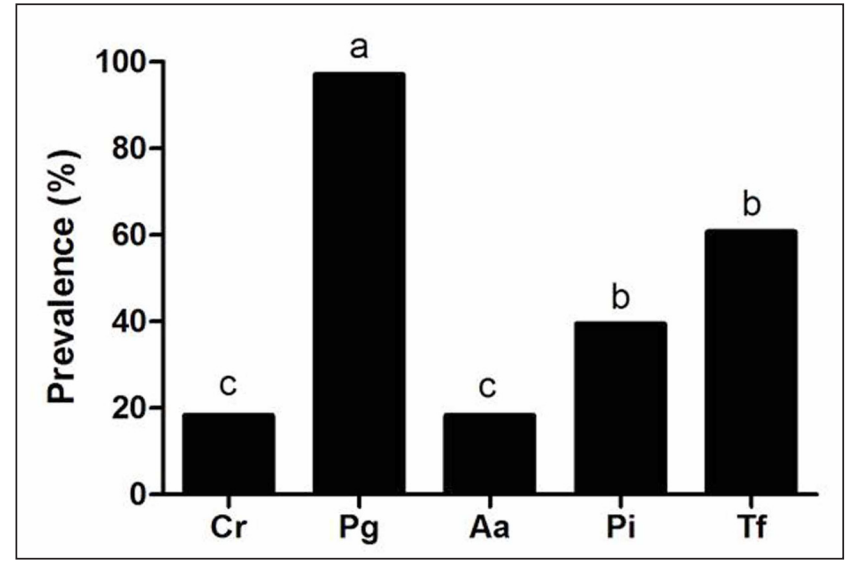

Fig. 2. The oral prevalence of periodontal pathogens within newborns from mothers with periodontal disease. Different lower case letters $(a, b, c)$ indicate a statistically significant difference $(P<0.05$, Chi-square test).

periodontal disease presents an infectious etiology (18) initiating from the colonization of specific pathogens, its early diagnosis is likely to be directly related to the detection of those pathogens in the oral cavity. Despite several studies that have shown the occurrence of the same bacterial species between mothers and their children with the aim of verifying a possible mechanism for the transmission, it is known that such expensive and high technology methodology has limited application in various populations worldwide, especially in developing and underdeveloped countries. In order to address this issue, the present study attempted to verify whether or not the motherly periodontal status, as assessed through a clinical examination, had the potential to predict the early oral occurrence of periodontal pathogens in their newborn children. Because any method used that may indicate a possible early acquisition of suspected periodontal pathogens is relevant and can contribute to prevent periodontal diseases $(19,20)$.

In various parts of the world, children have been affected by gingivitis, and, as indicated by reports from adult populations, a small proportion of children are also affected by periodontitis probably with similar etiological microbial factors. In this cross-sectional study, we have compared the frequencies of specific bacteria between newborns and their mothers who were either diagnosed or not diagnosed with periodontal disease and the process clearly revealed a difference in the characterization of the bacterial colonization. The intra-group analysis indicated that in the maternal group that was not diagnosed with periodontitis, the most prevalent bacterium was C. rectus $(23.25 \%)$, followed by other pathogens including T. forshythia (9.30\%), A. actinomycetemcomitans $(2.32 \%)$ whereas $P$. intermedia and $P$. gingivalis were not detected (Fig. 1). According to previous studies (21-23), our findings seem compatible with the mothers' periodontal clinical status, in principle, due to the remarkable relationship of $C$. rectus with periodontally healthy subjects. On the other hand, the intra-group analysis of newborns from the 
group of mothers who were diagnosed with periodontitis revealed a notable increase in the detection of species that are considered true periodontal pathogens $(23,24)$ including P. gingivalis (96.97\%), T. forshythia $(60.60 \%)$, and $A$. actinomycetemcomitans $(18.18 \%)$ in addition to the prevalence of $P$. intermedia $(39.39 \%$, which is known as a moderately common periodontal pathogen (Fig. 2).

The present study further analyzed an inter-group relationship. Aside from C. rectus, the other pathogens mentioned above were shown to be more prevalent among newborns from mothers who were diagnosed with periodontal disease. Although the purpose of this study was to verify a possible association between the maternal clinical periodontal status and the oral presence of specific bacterial species, our results appear to corroborate previous observations from studies that compared the oral microbiota of mothers and their sons $(5,8)$. Interestingly, our findings suggest that the presence of periodontal disease in the mother favors at least a transitory early appearance of periodontal pathogens in the newborn. Although this study is unable to state the precise moment of this transmission event and, above all, whether or not there will be a permanent colonization that could potentially lead to an infectious event, we must emphasize the importance of incorporating preventive strategies primarily for mothers since this would undoubtedly procure health benefits for their children. Simple procedures such as clinical periodontal examination performed during the pregnancy and during the latescent period can contribute to an increase in oral health. Of course, factors involving such procedures must be discussed with the obstetrician so that the adopted preventive and therapeutic decision will be in the best interest of both the mother and the child.

Pre-natal evaluation is currently a very rigorous and specific process involving several evaluations and laboratory examinations in order to bring about a thorough accompaniment of fetal development and analysis of the mother's clinical condition. This context appears to be an adequate opportunity to include a routine dental and periodontal evaluation on which the periodontics could determine what preventive and therapeutic procedures should be adopted in order to minimize this potential transmission.

Further studies are required to determine if the clinical periodontal status of the mother can serve as a potential risk factor that negatively impacts the child's oral health. Moreover, additional studies should be conducted to evaluate other groups close to newborns, such as groups composed of fathers and nurses.

\section{Conclusions}

The maternal clinical periodontal status was a satisfactory indicator of the early bacterial colonization pattern observed in their newborn offspring. Thus, longitudinal studies should be performed to confirm this relationship.

\section{Acknowledgments}

Financial support: FAPESP (Protocol\# 07/58340-0).

\section{References}

1. Tanaka S, Murakami Y, Ogiwara T, Shoji M, Seto K, Nagasaki M, Fujisawa S. Frequency of reactivity for Porphyromonas gingivalis and Prevotella spp. in supra- and subgingival plaques, and periodontal clinical parameters according to subject age. J Periodontol 2002; 73:877-85.

2. Cortelli JR, Cortelli SC, Jordan SF, Haraszthy VI, Zambon JJ. Prevalence of periodontal pathogens in brazilians with aggressive or chronic periodontitis. J Clin Periodontol 2005;32:860-6.

3. Bodet C, Chandad F, Grenier D. Pathogenic potential of Porphyromonas gingivalis, Treponema denticola and Tannerella forsythia, the red bacterial complex associated with periodontitis. Pathol Biol 2007;55:154-62.

4. Greenstein G, Lamster I. Bacterial transmission in periodontal diseases: a critical review. J Periodontol 1997;68:421-31.

5. Tamura K, Nakano K, Hayashibara T, Nomura R, Fujita K, Shintan $\mathrm{S}$, Ooshima T. Distribution of 10 periodontal bacteria in saliva samples from Japanese children and their mothers. Arch Oral Biol 2006; 51:371-7.

6. Rosa OP, Silva SM, Costa B, Torres SA, Passanezi E. Periodontopathogens in the saliva and subgingival dental plaque of a group of mothers. Pesqui Odontol Bras 2002;16:313-8.

7. Sakai VT, Campos MR, Machado MA, Lauris JR, Greene AS, Santos CF. Prevalence of four putative periodontopathic bacteria in saliva of a group of Brazilian children with mixed dentition: 1-year longitudinal study. Int J Paediatr 2007; 17:192-9.

8. Lee Y, Straffon LH, Welch KB, Loesche WJ. The transmission of anaerobic periodontopathic organisms. J Dent Res 2006;85:182-6.
9. Frisken KW, Higgins T, Palmer JM. The incidence of periodontopathic microorganisms in young children. Oral Microbiol Immunol 1990; 5:43-5.

10. Ooshima T, Nishiyama N, Hou B, Tamura K, Amano A, Kusumoto A, Kimura $S$. Occurrence of periodontal bacteria in healthy children: a 2-year longitudinal study. Community Dent Oral Epidemiol 2003;31:417-25

11. Umeda M, Miwa Z, Takeuchi Y, Ishizuka M, Huang Y, Noguchi K et al. The distribution of periodontopathic bacteria among Japanese children and their parents. J Periodontal Res 2004;39:398-404.

12. Kobayashi N, Ishihara K, Sugihara N, Kusumoto M, Yakushiji M, Okuda K. Colonization pattern of periodontal bacteria in Japanese children and their mothers. J Periodontal Res 2008;43:156-61.

13. Ximenez-Fyvie LA, Haffajee AD, Socransky SS. Comparison of the microbiota of supra and subgingival plaque in subjects in health and periodontitis. J Clin Periodontol 2000;27:648-57.

14. López NJ, Smith PC, Gutierres J. Periodontal therapy may reduce the risk of preterm low birth weight in women with periodontal disease: a randomized controlled trial. J Periodontol 2002;73:911-24.

15. Ashimoto A, Chen C, Bakker I, Slots J. Polymerase chain reaction detection of 8 putative periodontal pathogens in subgingival plaque of gingivitis and advanced periodontits lesions. Oral Microbiol Immunol 1996;1 1:266-73.

16. Slots J, Ashimoto A, Flynn MJ, Li G, Chen C. Detection of putative periodontal pathogens in subgingival specimens by $16 \mathrm{~S}$ ribossomal DNA amplification with the polymerase chain reaction. Clin Infect Dis 1995; 20 (Suppl 2):S304-7. 
17. Gjermo P, Rösing CK, Susin C, Oppermann R. Periodontal diseases in Central and South America. Periodontol 2000 2002;29:70-8.

18. Nunn ME. Understanding the etiology of periodontitis: an overview of periodontal risk factors. Periodontol 2000 2003;32:1 1-23.

19. Gonzalez M, Cabrera R, Grossi SG, Franco F, Aguirre A. Prevalence of dental caries and gingivitis in a population of Mexican schoolchildren. Community Dent Oral Epidemiol 1993;21:11-4.

20. Cunha ACP, Chambrone LA. Prevalência de gengivite em crianças. Rev Periodontia 1998;7:1-5.

21. Gajardo M, Silva N, Gómez L, León R, Parra B, Contreras A, Gamonal J. Prevalence of periodontopathic bacteria in aggressive periodontitis patients in a Chilean population. J Periodontol 2005; 76:289-94.
22. Lafaurie GI, Contreras A, Barón A, Botero J, Mayorga-Fayad I, Jaramillo A, Giraldo A, González F, Mantilla S, Botero A, Archila LH, Díaz A, Chacón T, Castillo DM, Betancourt M, Del Rosario Aya $M$, Arce R. Demographic, clinical, and microbial aspects of chronic and aggressive periodontitis in Colombia: a multicenter study. J Periodontol 2007;78:629-39.

23. Mayorga-Fayad I, Lafaurie GI, Contreras A, Castillo DM, Barón A, Aya Mdel R. Subgingival microbiota in chronic and aggressive periodontitis in Bogotá, Colombia: an epidemiological approach. Biomedica 2007; 27:21-33.

24. Tanner ACR, Paster BJ, Lu SC, Kanasi E, Kent JR, Van Dyke T, Sonis ST. Subgingival and tongue microbiota during early periodontitis. J Dent Res 2006;85:318-23. 